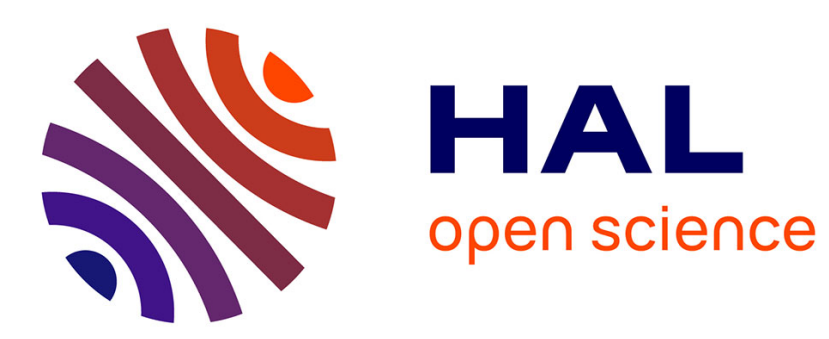

\title{
Clay formation and podzol development from postglacial moraines in Switzerland
}

Dominique Righi, Karine Huber, Catherine Keller

\section{To cite this version:}

Dominique Righi, Karine Huber, Catherine Keller. Clay formation and podzol development from postglacial moraines in Switzerland. Clay Minerals, 1999, 10.1180/000985599546253 . hal-01785726

\section{HAL Id: hal-01785726 \\ https://hal.science/hal-01785726}

Submitted on 4 May 2018

HAL is a multi-disciplinary open access archive for the deposit and dissemination of scientific research documents, whether they are published or not. The documents may come from teaching and research institutions in France or abroad, or from public or private research centers.
L'archive ouverte pluridisciplinaire HAL, est destinée au dépôt et à la diffusion de documents scientifiques de niveau recherche, publiés ou non, émanant des établissements d'enseignement et de recherche français ou étrangers, des laboratoires publics ou privés. 


\title{
Clay formation and podzol development from postglacial moraines in Switzerland
}

\author{
D. RIGHI, K. HUBER* AND C. KELLER ${ }^{\dagger}$ \\ UMR CNRS 6532 'Hydrogéologie, Argiles, Sols et Altérations' Faculté des Sciences, 86022 Poitiers Cedex, France, \\ *IATE/P-Pédologie, Département de Génie Rural, EPFL, 1015 Lausanne, and † Génie Sanitaire, Ecublens, EPFL, \\ 1015 Lausanne, Switzerland
}

(Received 28 August 1997; revised 8 September 1998)

\begin{abstract}
The fine silt $(2-5 \mu \mathrm{m})$ and fine clay $(<0.1 \mu \mathrm{m})$ fractions from four acid soils developed from moraines of increasing age (80, 400, 3,000 and 6,500 years old) in Switzerland, were studied by X-ray diffraction and chemical analyses. The soil parent material is homogeneous at the four sites and the soils can be considered as forming a chronosequence of soil development leading to the formation of Podzols. Mineralogical evolution of silt-sized phyllosilicates and fine clay fractions follows different pathways according to their composition and the soil horizon in which they are located. Dioctahedral and trioctahedral minerals in the soil parent material were both weathered in the $\mathrm{Bw}$ and Bs horizons but the trioctahedral phase more strongly and faster than the dioctahedral one. Weathering products are mica-vermiculite mixed-layers, vermiculite and finally gibbsite and $\mathrm{Fe}$ oxy-hydroxides. Weathering of the trioctahedral fraction was faster in the eluvial A or E horizons than in the B horizons, being almost complete after 3,000 years of soil development. Appreciable weathering of the dioctahedral fraction occurs only in the eluvial horizons leading to the formation of mica-smectite mixed-layers and smectite. Although smectite has been reported in the E horizon of Podzols in different environments, the significant finding in this work is the presence of this mineral in soils developed from the same parent material. This supports the fact that smectite is the endproduct of mica alteration in strongly leached and acidified E horizons of Podzols.
\end{abstract}

The rate of clay formation in soils from temperate areas is of great interest in order to address the problem of soil resilience. This rate is required to study the possible effects of acid deposition on soils, the elemental cycling and retention and loss of nutrients in forest ecosystems. The rate of weathering and the sorption properties of weathered products also strongly influence the chemistry of surface and subsurface waters.

Studies of weathering and clay formation rates require specific conditions to minimize the effect of soil-forming factors other than time (Jenny, 1941, 1980). Materials with identical characteristics exposed to weathering within various timespans must be selected in small areas to ensure that they were submitted to the same climatic events. Numerous weathering rate studies have been performed on volcanic ash deposits, which are generally well dated (Lowe, 1986), but there are fewer studies on glacial materials (Protz et al., 1984; Ugolini, 1986).

We studied clay formation in soils developed from moraine bodies of increasing age which were deposited in a small valley of the Mont-Blanc area (Val d'Arpette, Switzerland) by a glacier which progressively retreated during the post- and lateglacial periods.

\section{MATERIAL AND METHODS}

\section{Soil material}

A sequence of four soils was selected near the town of Martigny (Switzerland), in a small valley (Val d'Arpette) of the Mont-Blanc massif in the northern Alps area. Present climatic conditions for the lower part of the valley are $3.6^{\circ} \mathrm{C}$ mean annual temperature and $951 \mathrm{~mm}$ mean annual precipitation. 
The valley, which was excavated by a small glacier, is $\sim 6 \mathrm{~km}$ long, rising from 1460 to $3260 \mathrm{~m}$. During the late- and post-glacial periods, the glacier retreated up-valley by successive stages, leaving moraine bodies at increasing altitudes. Estimation of the age of the successive moraines is based on several geomorphological studies that have established expansion and retreat for glaciers in the Mont-Blanc area (Burri, 1974; Bless, 1984; Holzhauser, 1984). All the morainic materials were produced through glacial transport within a small area of homogeneous bedrock constituted by the Mont-Blanc granite.

Four profiles were sampled, all of which were in the same north-facing, sub-summital or summital topographic position.

Soil \#1. Rankosol alpin (INRA, 1995), Typic Cryorthent (Soil Survey Staff, 1992) developed from a barren, unconsolidated stony moraine at an altitude of $2380 \mathrm{~m}$. The moraine was deposited 80 years ago. Differentiation of horizons in this soil is extremely weak; only a slight change to a more yellowish colour was observed in the first $7 \mathrm{~cm}$ below the surface.

Soil \#2. Brunisol oligo-saturé, Typic Cryumbrept, developed at $2200 \mathrm{~m}$ from an unconsolidated moraine $\sim 400$ years old. At this site the vegetation is limited to a discontinuous cover of alpine meadow. An organo-mineral A horizon, $10 \mathrm{~cm}$ thick, overlying a poorly expressed $\mathrm{Bw}$ (or $\mathrm{S}$, INRA, 1995) horizon was observed.

Soil \#3. Podzosol ocrique, Entic Cryorthod, developed at $2165 \mathrm{~m}$ from a stable moraine $(\sim 3000$ years old) which is now totally covered by blueberry bushes. An organo-mineral A horizon, $15-20 \mathrm{~cm}$ thick, is present overlying a podzolic Bs horizon.

Soil \#4. Podzosol durique, Typic Cryorthod, developed at $2000 \mathrm{~m}$ from a moraine ( 6500 years old) covered by rhododendron bushes and larch trees. A typical $\mathrm{E}$ horizon, $5-10 \mathrm{~cm}$ thick, is present, overlying typical podzolic $\mathrm{Bh}$ and Bs horizons.

The $\mathrm{C}$ horizon from soil \#1 (assumed to be the parent material), the $\mathrm{Bw}$ and $\mathrm{Bs}$ horizons from soils $\# 2,3$ and 4, the A horizons from soils \#2 and 3 and the $\mathrm{E}$ horizon from soil \#4 were sampled for the study.

\section{Methods}

The silt $(2-5,5-10,10-20 \mu \mathrm{m})$ and clay fractions $(<2 \mu \mathrm{m})$ were obtained from the soil samples by sedimentation after destruction of organic matter with diluted, $\mathrm{Na}$ acetate buffered $\mathrm{H}_{2} \mathrm{O}_{2}$ and dispersion at $\mathrm{pH}=9(\mathrm{NaOH})$. After citrate-bicarbonate-dithionite (CBD) treatment (Mehra \& Jackson, 1960) the bulk clay fraction was divided into fine $(<0.1 \mu \mathrm{m})$ and coarse clay $(0.1-2 \mu \mathrm{m})$ sub-fractions using a Beckman J2-21 centrifuge equipped with the JCF-Z continous flow rotor.

X-ray diffraction (XRD) diagrams were obtained from oriented specimens using a Philips diffractometer with $\mathrm{Fe}$-filtered $\mathrm{Co}-K \alpha$ radiation. Randomly oriented powders were used to obtain the 060 bands. The diffractograms were recorded numerically by a DACO-MP recorder using the DiffracAT software (SOCABIM, France). Pretreatments of the specimens included $\mathrm{Ca}$ saturation and solvation with ethylene glycol and also $\mathrm{K}$ saturation and heating at $350^{\circ} \mathrm{C}$. The Greene-Kelly (1953) test was used to distinguish montmorillonite from beidellite. The XRD diagrams were decomposed into their elementary component curves using the DecompXR program of Lanson (1993). The number of elementary curves was progressively increased, in order to obtain a good fit with the smallest number of curves. Simulation of XRD patterns were made with the NEWMOD program (Reynolds, 1985) to help the identification of mixed-layer minerals.

Amorphous forms of $\mathrm{Fe}$ and $\mathrm{Al}$ oxides and hydroxides were extracted from the bulk soil $(<2 \mathrm{~mm})$ with the $\mathrm{NH}_{4}$ oxalate reagent (Schwertmann, 1964). The CBD treatment was used to extract amorphous plus crystalline forms of $\mathrm{Fe}$ oxides. Extracted $\mathrm{Al}$ and $\mathrm{Fe}$ were analysed using atomic absorption spectrometry (AAS).

Total chemical analyses were performed on the $<0.1 \mu \mathrm{m}$ sub-fractions according to the procedure described by Jeanroy (1972). Silicon, Al, Fe, Ti, $\mathrm{Mg}, \mathrm{Ca}, \mathrm{Na}$ and $\mathrm{K}$ were analysed using AAS. The accessible permanent charge was measured according to the procedure of Anderson \& Sposito (1991). The method is based on the preference of siloxane surface exchange sites for Cs over $\mathrm{Li}$ and on the much lower selectivity of ionizable surface groups for Cs. This method allows us to separate the contribution of structural permanent charge and $\mathrm{pH}$-dependent charge to total cationic exchange capacity. Acid treatment ( $\mathrm{M} \mathrm{HCl}, 80^{\circ} \mathrm{C}$, overnight) was used to dissolve trioctahedral and Fe-rich dioctahedral minerals (MacEwan \& Wilson, 1980). Individual particles of coarse clay $(0.1-2 \mu \mathrm{m})$ and fine silt sub-fractions $(2-5 \mu \mathrm{m})$ were analysed with a scanning electron microscope (SEM; Jeol JMS 
6400) equipped with an EDS analyser (Kevex). Thermogravimetric (TGA) and differential thermal analysis (DTA) curves were obtained using a Netzsch STA 409 EP thermal-analyser. The $\mathrm{Fe}^{2+} / \mathrm{Fe}^{3+}$ ratios were computed from ${ }^{57} \mathrm{Fe}$ Mössbauer spectroscopy data obtained at room temperature, using a $50 \mathrm{mCi},{ }^{57} \mathrm{Co} / \mathrm{Rh}$ source, and a MSC ORTEC multichannel analyser.

\section{RESULTS}

\section{Bulk soil $(<2 \mathrm{~mm})$}

All the soils have a sandy loam texture with a maximum of $13.4 \%$ clay in the Bh horizon of the most developed soil (\#4) (Table 1). The particlesize distribution curves from the $\mathrm{C}$ horizon samples (Fig. 1) have the same concave pattern, except the concavity of the curve decreases slightly with the age of the soil. The particle-size distribution curves from the $\mathrm{Bw}$ and $\mathrm{Bs}$ samples exhibit the same pattern (not shown). The maximum clay content increases with soil age from $1.7 \%$ (soil \#1, C horizon) to $13.4 \%$ (soil \#4, Bh horizon). The increase in clay content is a non-linear function of time, the rate of clay formation decreasing with time (Fig. 2). The amounts of $\mathrm{NH}_{4}$ oxalate extractable $\mathrm{Al}$ and $\mathrm{Fe}$ increase with soil age from
$0.19-0.14 \mathrm{~g} \mathrm{~kg}^{-1}(\mathrm{Al})$ and $0.34-0.24 \mathrm{~g} \mathrm{~kg}^{-1}(\mathrm{Fe})$ in soil \#1 to $12.96 \mathrm{~g} \mathrm{~kg}^{-1}$ (Al) and $31.71 \mathrm{~g} \mathrm{~kg}^{-1}$ $(\mathrm{Fe})$ in the $\mathrm{Bs}$ and $\mathrm{Bh}$ horizon of soil \#4, respectively (Table 1 ). Moreover, the maximum accumulation occurs in the A horizon for the two youngest soils and in the Bs or Bh horizon for the two older. This may be attributed to the development, with time, of the podzolization process. The total chemical analysis of the bulk soil samples from the four $\mathrm{C}$ horizons (Table 2) show that these horizons ar all similar chemically.

\section{Silt fractions}

$X$-ray diffraction. Similar XRD diagrams were obtained from the different silt fractions (2-5; $5-10 ; 10-20 \mu \mathrm{m}$ ), and so only the diagrams from the $2-5 \mu \mathrm{m}$ fractions are shown here (Fig. 3). All the samples exhibit characteristic peaks for micas $(1.002 ; 0.500 ; 0.333 \mathrm{~nm})$, quartz $(0.427 ; 0.335 \mathrm{~nm})$, feldspars $(0.404 ; 0.320 ; 0.325 \mathrm{~nm})$ and kaolinite $(0.355 \mathrm{~nm})$. Moreover, mica is the dominant mineral in the $\mathrm{C}$ horizon of soil \#1 associated with some chlorite $(1.436 ; 0.713 ; 0.473$ and $0.350 \mathrm{~nm}$ ). Chlorite is also present in the samples from the $\mathrm{Bw}$ and Bs horizons but not in those from the $\mathrm{A}$ and $\mathrm{E}$ horizons of the two older soils (\#3, $3000 \mathrm{YBP}$ and \#4, $6500 \mathrm{YBP})$. With increasing age

TABLE 1. Some characteristics of the soil horizon samples.

\begin{tabular}{|c|c|c|c|c|c|c|c|}
\hline Soil, horizon & $\mathrm{P} \mathrm{cm}$ & $\mathrm{pH}-\mathrm{H}_{2} \mathrm{O}$ & CEC & clay $(<2 \mu \mathrm{m})$ & $\mathrm{OC}$ & $\mathrm{Al} \mathrm{NH}{ }_{4}-\mathrm{Ox}$ & $\mathrm{Fe} \mathrm{NH}_{4}$-ox \\
\hline$\# 1$ A & $0-7$ & 5.0 & 1.82 & 1.5 & 0.5 & 0.19 & 0.34 \\
\hline$\# 1 \mathrm{C}$ & $>50$ & 5.8 & 0.85 & 1.7 & 0.1 & 0.14 & 0.24 \\
\hline$\# 2 \mathrm{~A}$ & $0-12$ & 4.5 & - & 6.3 & 11.4 & 1.26 & 3.21 \\
\hline$\# 2 \mathrm{Bw}$ & $12-27$ & 5.0 & 2.87 & 2.5 & 4.9 & 0.56 & 1.15 \\
\hline$\# 2 \mathrm{C}$ & $27-50$ & 5.4 & 1.94 & 2.3 & 0.7 & 0.43 & 0.67 \\
\hline$\# 3$ A & $0-20$ & 4.7 & 8.79 & 9.0 & 9.8 & 2.97 & 5.06 \\
\hline \#3 Bs & $20-40$ & 4.7 & 6.60 & 4.5 & 2.9 & 5.97 & 5.96 \\
\hline \#3 Bs/C & $40-60$ & 5.1 & 3.18 & 1.4 & 0.9 & 3.06 & 1.51 \\
\hline$\# 3 \mathrm{C}$ & $>60$ & 5.2 & 2.03 & 2.0 & 0.8 & 2.78 & 1.16 \\
\hline$\# 4 \mathrm{~A}$ & $0-7$ & 4.0 & 16.10 & - & 39.0 & 0.6 & 1.34 \\
\hline \#4 E & $7-9$ & 4.4 & 3.90 & 3.9 & 3.3 & 3.07 & 3.25 \\
\hline \#4 Bh & $9-15$ & 4.3 & 18.76 & 13.4 & 9.0 & 7.88 & 31.71 \\
\hline \#4 Bs & $15-60$ & 4.8 & 8.04 & 9.5 & 3.2 & 12.96 & 15.87 \\
\hline \#4 C & $>60$ & 5.1 & 2.53 & 4.0 & 0.8 & 4.53 & 1.26 \\
\hline
\end{tabular}

P: depth, cm; CEC: cation exchange capacity, $\mathrm{cmol}_{\mathrm{c}} \mathrm{kg}^{-1}$; clay: per cent $105^{\circ} \mathrm{C}$ dry soil: $\mathrm{OC}$ : organic carbon, per cent $105^{\circ} \mathrm{C}$ dry soil: $\mathrm{Al}, \mathrm{Fe} \mathrm{NH}_{4}$-ox: $\mathrm{NH}_{4}$-oxalate extractable $\mathrm{Al}$ and $\mathrm{Fe}, \mathrm{g} \mathrm{kg}^{-1} 105^{\circ} \mathrm{C}$ dry soil 


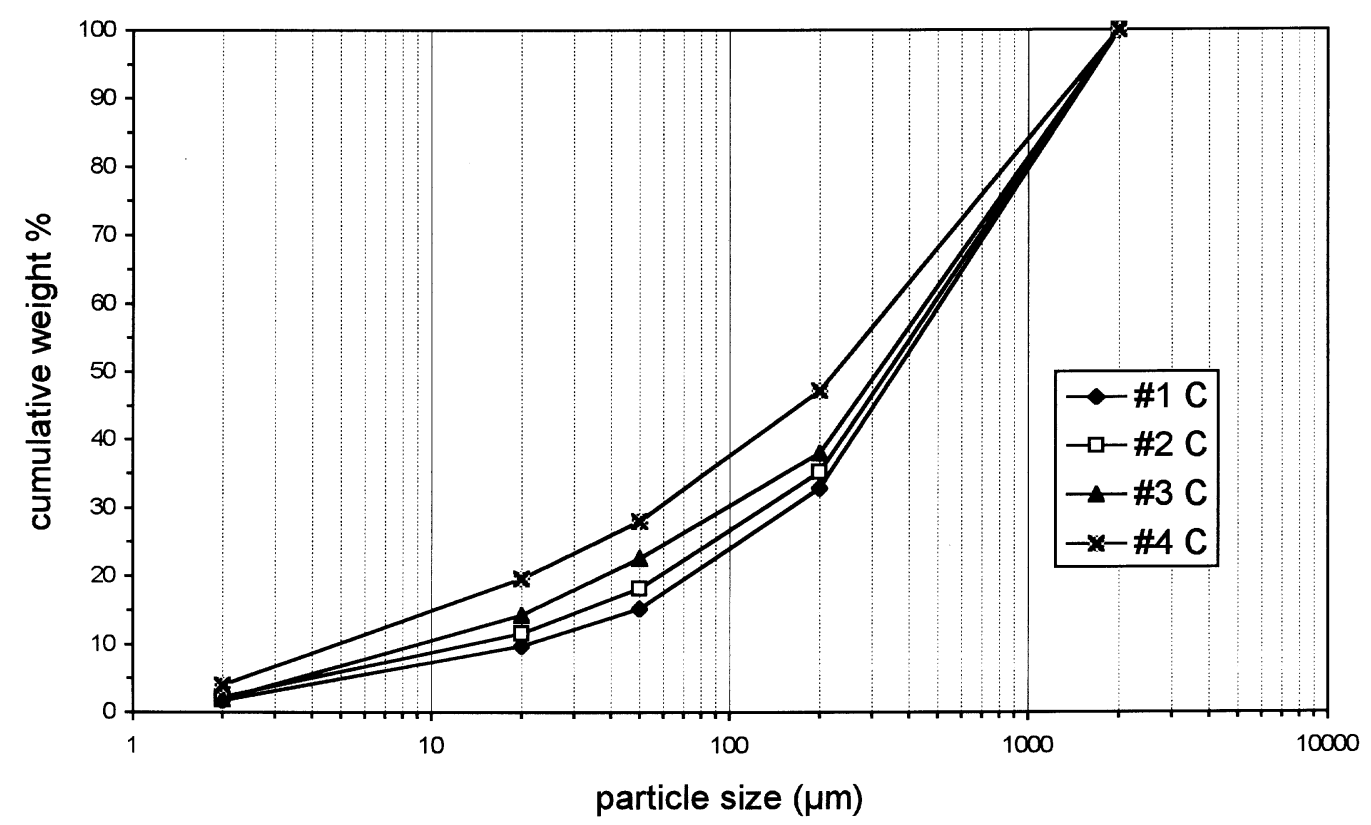

FIG. 1. Cumulative grain size distribution curves for the $\mathrm{C}$ horizons for the four soils.

the most striking mineralogical evolution in the $\mathrm{Bw}$ and Bs samples is the development of two peaks near $d=1.45$ and $1.22-1.25 \mathrm{~nm}$ that shifted to $\sim 1.00 \mathrm{~nm}$ after $\mathrm{K}$ saturation and heating at $300^{\circ} \mathrm{C}$ (not shown) and attributed to vermiculite and micavermiculite mixed-layers, respectively. The fine silt fractions from the A (soil \#3) and E horizons (soil \#4) are characterized by the development of fully ordered mica-smectite mixed-layers, as shown by superstructure diffraction peaks near 2.50 and $1.25 \mathrm{~nm}$ for air-dried samples. The positions of these peaks were affected by ethylene glycol solvation: shifting from 2.50 and $1.25 \mathrm{~nm}$, in the air-dried state, to $2.70-2.718$ and $1.256-1.34 \mathrm{~nm}$

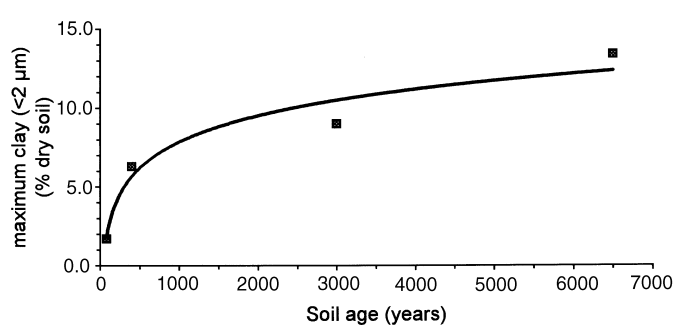

FIG. 2. Maximum clay content $(<2 \mu \mathrm{m})$ in the soils $v s$. time of soil development. after ethylene glycol solvation; this indicates a smectite component in the mixed-layers. According to simulations with the NEWMOD program (Reynolds, 1985), the proportion of smectite in these mixed-layers may be estimated at about $50 \%$ in soil \#3 (A horizon) and $\sim 70 \%$ in soil \#4 (E horizon).

Chemical composition. The $\mathrm{Fe}^{2+} / \mathrm{Fe}^{3+}$ ratios for the bulk silt fractions were obtained from CBDtreated samples by Mössbauer spectroscopy. This ratio decreases with soil age from 0.79 (soil \#1, C horizon) to 0.56 (soil \#2, Bw horizon), 0.45 (soil \#3, Bs horizon) and 0.39 (soil \#4, Bs horizon). Chemical analyses of individual silt particles were obtained using a SEM equipped with an EDS probe. Results are expressed in an $M^{+}-R^{2+}-4 \mathrm{Si}$ ternary diagram (Righi \& Meunier, 1991). The $\mathrm{Fe}^{2+} / \mathrm{Fe}^{3+}$ ratios obtained from the bulk silt fractions were used to evaluate the $\mathrm{Fe}^{2+}$ content that was allocated to the $R^{2+}$ pole.

Silt particles from the $\mathrm{C}$ horizon of soil \#1 have chemical compositions clustered within three domains (Fig. 4). One domain belongs to the chemical composition field of phengitic mica, the second extends between the chemical composition fields of ideal biotite and soil vermiculite derived from trioctahedral mica (Douglas, 1989), and the 
TABLE 2. Chemical composition of the bulk soil sample $(<2 \mathrm{~mm})$ from the $\mathrm{C}$ horizons of the four studied soils $\left(\% 1000^{\circ} \mathrm{C}\right.$ dry soil).

\begin{tabular}{lrrrrrrrr}
\hline & $\mathrm{SiO}_{2}$ & $\mathrm{Al}_{2} \mathrm{O}_{3}$ & $\mathrm{Fe}_{2} \mathrm{O}_{3}$ & $\mathrm{MnO}_{2}$ & $\mathrm{~K}_{2} \mathrm{O}$ & $\mathrm{Na}_{2} \mathrm{O}$ & $\mathrm{CaO}$ & $\mathrm{TiO}_{2}$ \\
\hline soil \#1 & 78.00 & 11.75 & 1.50 & 0.03 & 3.76 & 3.38 & 0.98 & 0.23 \\
soil \#2 & 77.36 & 11.18 & 2.44 & 0.06 & 3.81 & 3.19 & 1.01 & 0.32 \\
soil \#3 & 75.45 & 12.54 & 2.86 & 0.08 & 3.79 & 3.05 & 1.09 & 0.35 \\
soil \#4 & 80.98 & 7.86 & 2.49 & 0.06 & 3.82 & 3.19 & 0.71 & 0.32 \\
\hline
\end{tabular}

third one belongs to the chemical composition field of chlorite. In good agreement with the results obtained by XRD, particle analyses indicate siltsized chlorite and micas in this horizon. Analyses indicate that micas comprise a dioctahedral phengitic mica and an Fe-, Mg-rich biotitic one. Identical results were obtained for the Bs horizon of soil \#4 (Fig. 4) and the Bw and Bs horizons of soils \#2 and \#3 (not shown). The chemical compositions of the phengitic particles are very homogeneous, suggesting that the phengite mica is not, or only slightly, weathered. Conversely, particles other than phengite appear to have a wider domain of chemical compositions. In particular, large changes in the proportion of $R^{2+}$ cations $\left(\mathrm{Mg}^{2+}\right.$ and $\mathrm{Fe}^{2+}$ ) were measured. This may indicate biotitic and chloritic particles at different weathering stages, in agreement with the formation of vermiculite and mica-vermiculite mixed-layers as shown by XRD.

In the silt fraction from the $\mathrm{E}$ horizon of the oldest profile (soil \#4), only phengitic particles were analysed, and their chemical compositions are more scattered than in the $\mathrm{Bw}$ and Bs horizon samples. This suggests that in the E horizon most of the silt-sized Fe, Mg-rich minerals (biotite, chlorite) were totally dissolved and the phengite mica partially weathered.

\section{Fine clay fractions}

$X$-ray diffraction. The XRD diagram from the fine clay fraction of the youngest soil (\#1) shows essentially a mica phase $(1.002,0.500 \mathrm{~nm})$. The $1.00 \mathrm{~nm}$ peak exhibits a large asymmetry towards low ${ }^{\circ} 2 \theta$ angles indicative of mica-vermiculite mixed-layers. Small amounts of chlorite are also present $(1.426 ; 0.713 ; 0.473 ; 0.355 \mathrm{~nm})$. Finegrained feldspar $(0.320 ; 0.325 \mathrm{~nm})$ particles are also detected as minor components (Fig. 5).

In the sample from the $\mathrm{Bw}$ horizon of soil $\# 2$, the most intense diffraction peak is at $d=1.682 \mathrm{~nm}$ (ethylene glycol) and attributed to smectite layers. Compared to that of soil \#1 the intensity of the peak at $d=1.426 \mathrm{~nm}$ is increased. This peak was shifted to $\sim 1.0 \mathrm{~nm}$ after $\mathrm{K}$ saturation and heating at $350^{\circ} \mathrm{C}$ (not shown) and consequently attributed to vermiculite layers. Chlorite is present. The XRD diagrams from the Bs horizon of the two older soils (\#3 and 4) are characterized by a general decrease of the diffracted intensities, indicating low crystallinity of minerals in these horizons. Gibbsite $(0.473$; $0.437 \mathrm{~nm}$ ) occurs in these horizons, and is the main component of the fine clay fraction from the Bs horizon of the oldest soil (\#4).

The XRD diagrams from the samples of the A and $\mathrm{E}$ horizons do not exhibit the same mineral suite as for their corresponding $\mathrm{Bw}$ or Bs horizons. In the fine clay samples from the A and $\mathrm{E}$ horizon, XRD indicates an ordered mica-smectite mixedlayer $(2.665 ; 1.271 \mathrm{~nm})$ associated with smectite $(1.696 \mathrm{~nm})$. Chlorite is present in the A horizon from soil $\# 2$, but not in the $\mathrm{A}$ and $\mathrm{E}$ horizon of soil $\# 3$ and \#4. Kaolinite is present in these horizons as indicated by intense peaks at $d=0.720$ and $0.355 \mathrm{~nm}$. Another feature is the decreasing intensity of the peak of mica $(1.002 \mathrm{~nm})$ with soil age.

The XRD diagrams from randomly oriented powders of the fine clay samples were decomposed in the $70-75^{\circ} 2 \theta$ region, using DecompXR (Fig. 6) to obtain the 060 reflections. For the fine clay sample from soil \#1 (C horizon), five elementary curves are needed to fit with the experimental curve: two at $d=0.154 \mathrm{~nm}$ (but with two different widths and intensities); the more intense is attributed to trioctahedral minerals (mica and chlorite) and the less intense to quartz; one at $d=$ $0.152 \mathrm{~nm}$, attributed to Fe-rich dioctahedral minerals (Fanning et al., 1989); one at $d=$ $0.151 \mathrm{~nm}$, attributed to dioctahedral aluminous minerals and one at $d=0.150 \mathrm{~nm}$ that could be attributed to chlorite and/or kaolinite. The same 


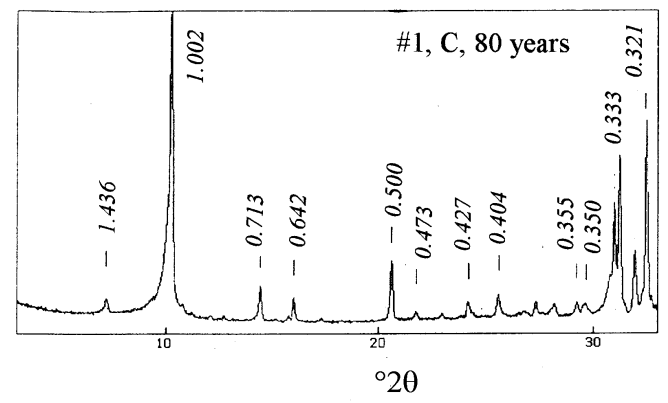

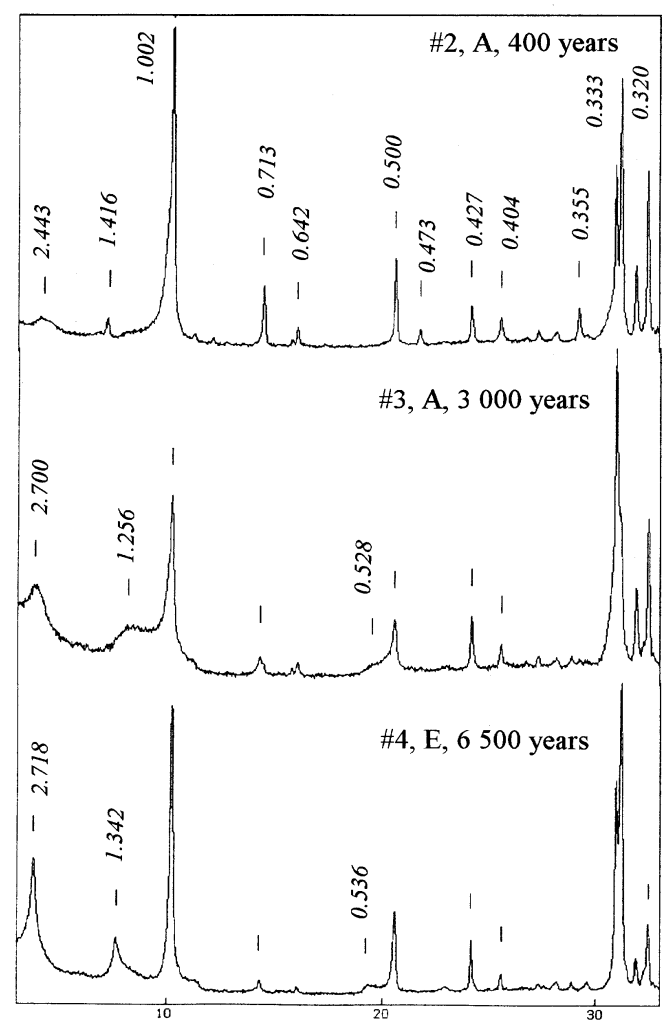

${ }^{\circ} 2 \theta$

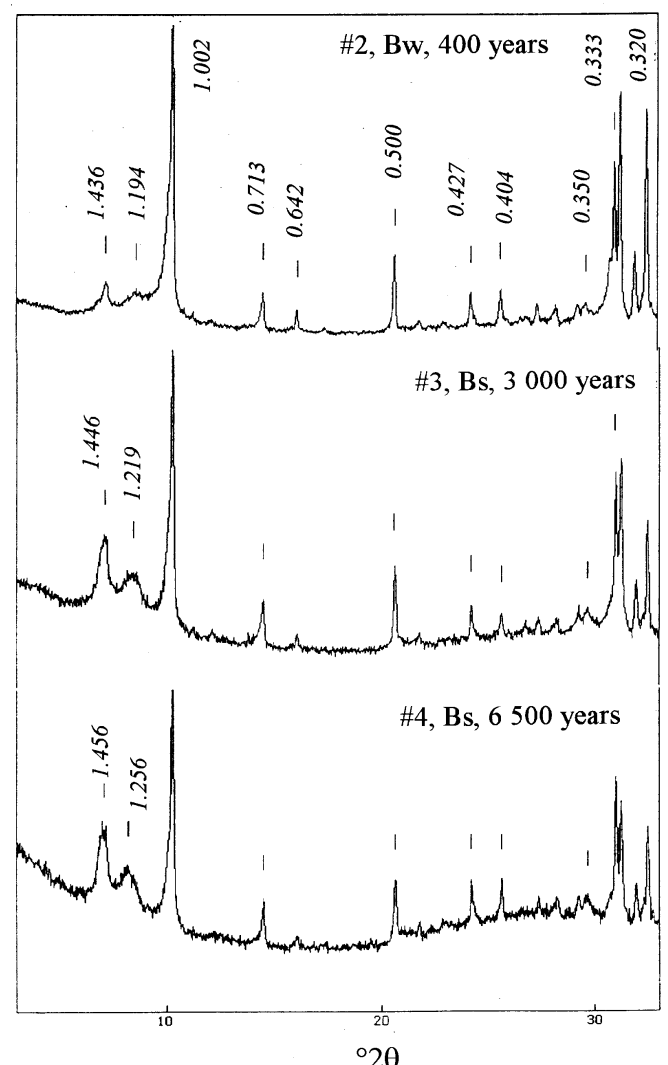

${ }^{\circ} 2 \theta$

FIG. 3. XRD diagrams for the fine silt fractions $(2-5 \mu \mathrm{m}), \mathrm{Ca}-\mathrm{saturated}$, ethylene glycol solvated samples, Co- $K \alpha$ radiation, $d$-spacings in $\mathrm{nm}$. Samples: soil \#1, C horizon, 80 years old; soil \#2, A (left) and Bw (right) horizons, 400 years old; soil \#3, A (left) and Bs (right) horizons, 3000 years old; soil \#4, E (left) and Bs (right) horizons, 6500 years old.

elementary curves are needed for the decomposition of the XRD patterns from the fine clay samples of the $\mathrm{Bw}$ and Bs horizons from soils \#2, \#3 and \#4. For these samples the curve at the lowest ${ }^{\circ} 2 \theta$ position is attributed to quartz. From soil \#1 (C horizon) to soil \#4 (Bs horizon) the most important feature is the decrease in the relative intensity of the peak at $d=0.154 \mathrm{~nm}$ attributed to trioctahedral minerals, as compared to that of the peak at $d=$ $0.151 \mathrm{~nm}$. In soils \#2, \#3 and \#4 the XRD patterns 


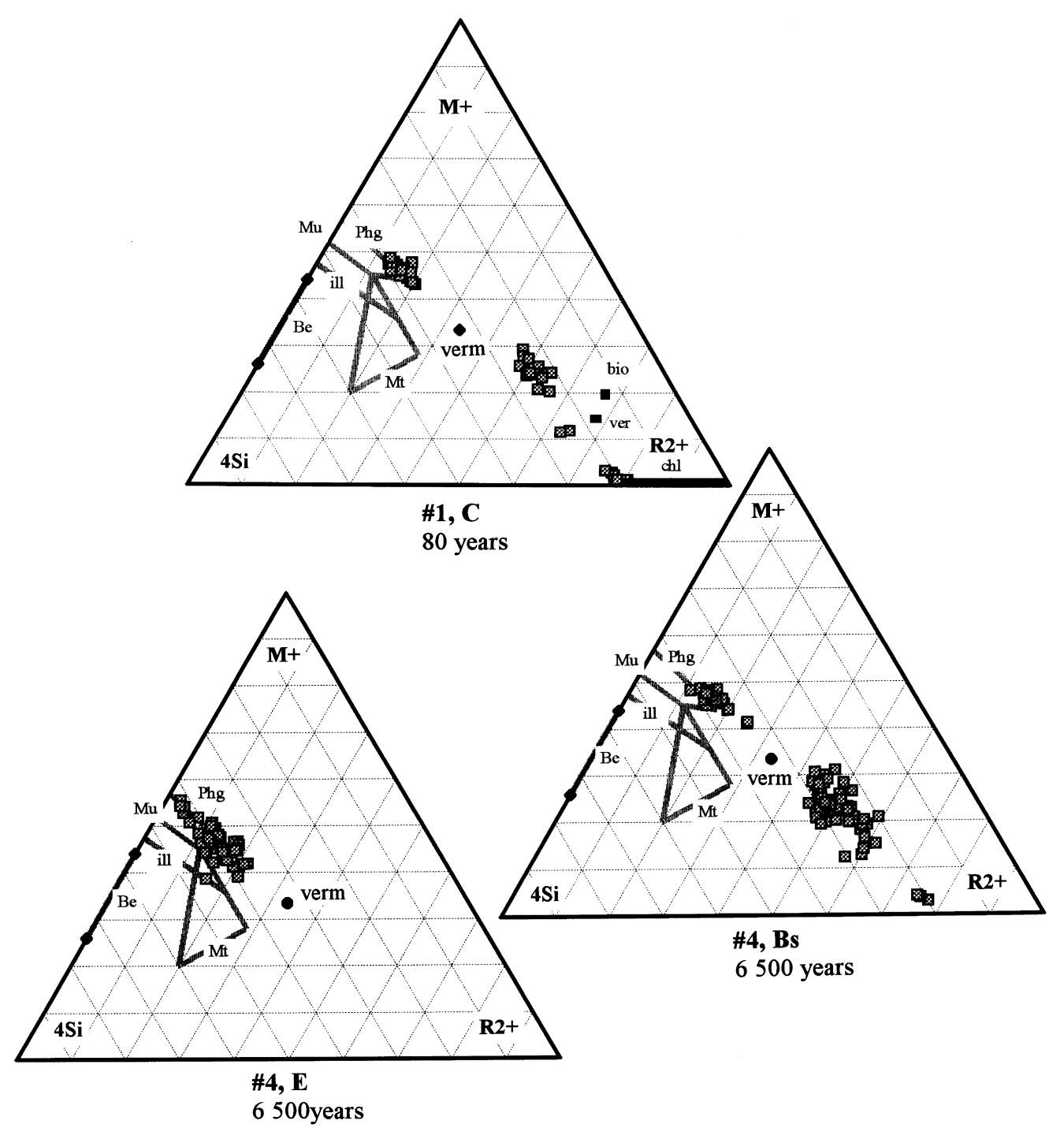

FIG. 4. Chemical composition of individual particles $(2-5 \mu \mathrm{m})$ plotted in a ternary $M^{+}-4 \mathrm{Si}-R^{2+}$ diagram: $\mathrm{Be}=$ beidellite, $\mathrm{Mt}=$ montmorillonite, $\mathrm{Phg}=$ phengite, $\mathrm{Bio}=$ biotite, $\mathrm{Ver}=$ tri-octahedral vermiculite, Verm $=$ soil vermiculite, Chlo $=$ chlorite, Ill $=$ illite, $\mathrm{Mu}=$ muscovite chemical composition fields. Samples: soil \#1, C horizon, 80 years old; soil \#4, E (left) and Bs (right) horizons, 6500 years old.

obtained from the samples of the A and E horizons are different from those of the corresponding $\mathrm{Bw}$ and Bs horizon samples. The intensities of the peaks at $d=0.154$ and $0.152 \mathrm{~nm}$ are low. Except for the small sharp peak at $d=0.154 \mathrm{~nm}$ attributed to quartz, these peaks are not present in the $\mathrm{E}$ horizon sample from soil \#4 for which the two intense peaks at $d=0.151$ and $d=0.149 \mathrm{~nm}$ are attributed to dioctahedral minerals (mica, smectite, mica-smectite mixed-layer) and kaolinite, respectively.

The Greene-Kelly test was used on fine clay samples exhibiting diffraction peaks characteristic for smectite layers. After Li saturation and heating, a partial re-expansion after glycol solvation was observed (Fig. 7), indicating that at least a part of 

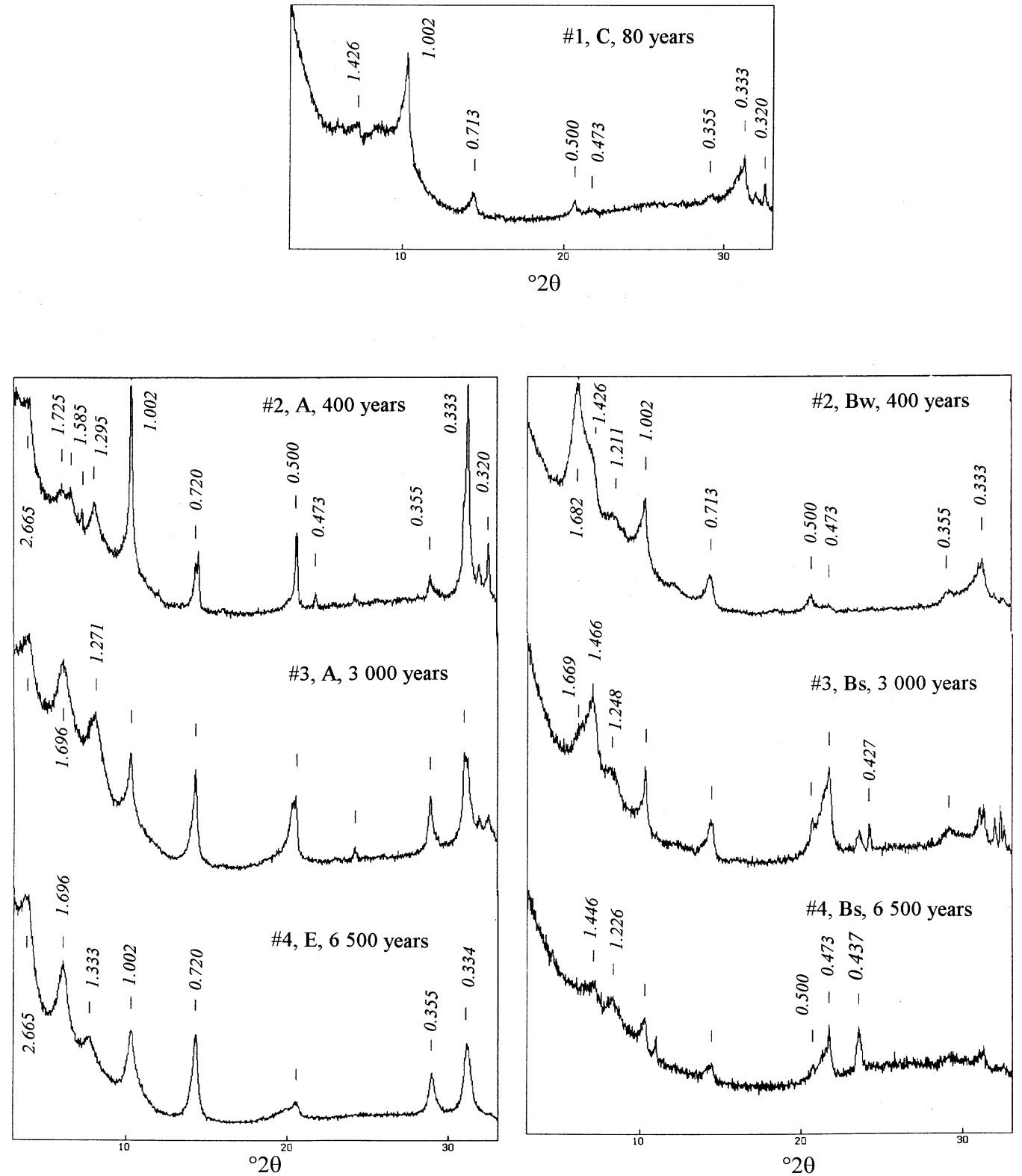

FIG. 5. XRD diagrams for the fine clay fractions $(<0.1 \mu \mathrm{m})$, Ca-saturated, ethylene glycol solvated, Co- $K \alpha$ radiation, $d$-spacings in $\mathrm{nm}$. Samples: soil \#1, C horizon, 80 years old; soil \#2, A (left) and Bw (right) horizons, 400 years old; soil \#3, A (left) and Bs (right) horizons, 3000 years old; soil \#4, E (left) and Bs (right) horizons, 6500 years old.

the smectite layers are beidellitic. For the sample from soil \#4, E horizon, the smectite component of the ordered mica-smectite mixed-layer is montmorillonitic, as the peaks attributed to that mineral were shifted to $d=1.005 \mathrm{~nm}$ after the Greene-Kelly treatment.

Acid treatment. The fine clay fraction from the Bw horizon of soil \#2 contains mica, mica- 
Podzols in postglacial moraines

327
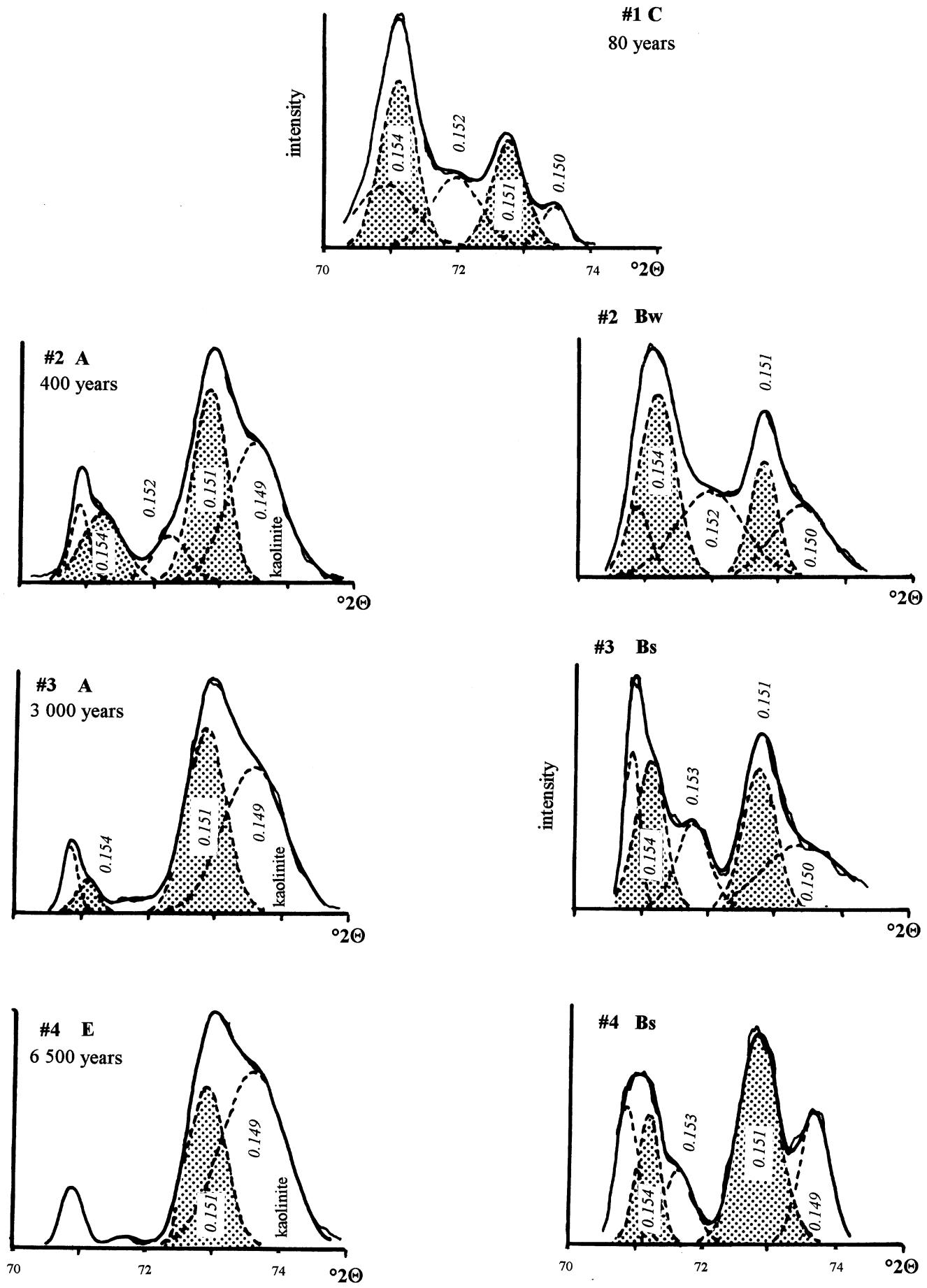

FIG. 6. Decomposed XRD diagrams. Fine clay fractions $(<0.1 \mu \mathrm{m})$, random oriented samples (same samples as in Fig. 5). - experimental curve; --- computed elementary curve; $\longrightarrow$ best-fit computed curve. 


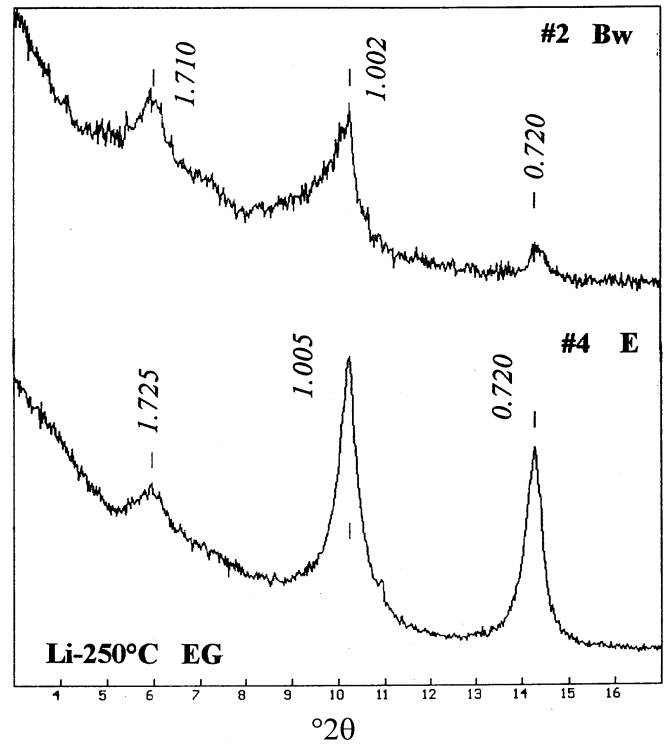

FIG. 7. XRD diagrams for Greene-Kelly treated fine clay samples, ethylene glycol solvated, Co- $K \alpha$ radiation, $d$-spacings in $\mathrm{nm}$. Samples: soil \#2 (upper), Bw horizon, 400 years old; soil \#4 (lower), E horizon, 6500 years old.

vermiculite mixed-layers, vermiculite and smectite. As indicated by the position of the 060 reflections, these minerals could be either di- or tri-octahedral. To solve the ambiguity, acid treatment $(\mathrm{M} \mathrm{HCl}$, $80^{\circ} \mathrm{C}$, overnight) was carried out as this treatment is reputed to solubilize trioctahedral and Fe-rich dioctahedral minerals (MacEwan \& Wilson, 1980). The XRD pattern of the treated sample was then decomposed in the $5-12$ and $70-75^{\circ} 2 \theta$ regions and compared with that of the untreated sample. The XRD pattern of the treated sample in the $70-75^{\circ} 2 \theta$ region (not shown) confirms the dissolution of trioctahedral minerals by the acid treatment. The XRD pattern of the untreated sample may be decomposed with four major elementary curves with their maximum at $d=1.676,1.476,1.221$ and $0.998 \mathrm{~nm}$ attributed to smectite, vermiculite, micavermiculite and mica, respectively. After the acid treatment, the XRD pattern was changed dramatically (Fig. 8): the elementary curves with their maximum at $d=1.476$ and $1.221 \mathrm{~nm}$ are not needed for the decomposition. This suggests that at least some of the smectite and mica layers are dioctahedral, but the vermiculite and mica-vermiculite mixed-layers are trioctahedral and/or Fe-rich minerals. The same treatment applied to the fine
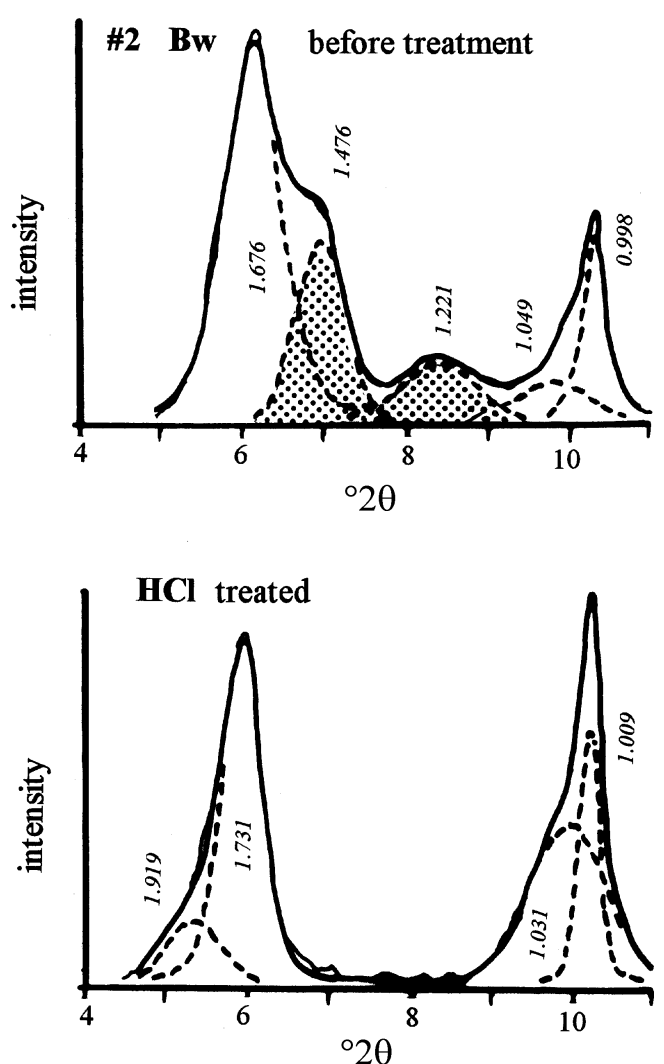

FIG. 8. Decomposed XRD diagrams for untreated and $\mathrm{HCl}$ treated $\# 2 \mathrm{Bw}$ sample $(\# 2, \mathrm{Bw})$. Fine clay fractions, parallel-oriented samples, Ca-saturated, ethylene glycol solvated, Co- $K \alpha$ radiation, $d$-spacings in $\mathrm{nm}$. experimental curve; - _ - computed elementary curve; $\longrightarrow$ best-fit computed curve.

clay from the A horizon of soil \#3 leads to the decrease of the intensity of the peak at $d=1.69 \mathrm{~nm}$, and the peaks near 2.70 and $1.35 \mathrm{~nm}$ attributed to ordered mica-smectite mixed-layers are better preserved. According to the susceptibility to the acid treatment, smectite in this sample would be dioctahedral and $\mathrm{Fe}$ rich (no trioctahedral minerals are present in this sample).

TGA and DTA. The DTA curves (Fig. 9) of the samples from the Bs horizons (soils \#3 and \#4) exhibit a sharp endothermic peak at $280^{\circ} \mathrm{C}$, characteristic of gibbsite. The amount of gibbsite in the fine clay fraction was computed using the weight loss between 220 and $310^{\circ} \mathrm{C}$. No gibbsite occurs in the parent material (soil \#1) or in the A and $\mathrm{E}$ horizons of the other soils. Gibbsite is 


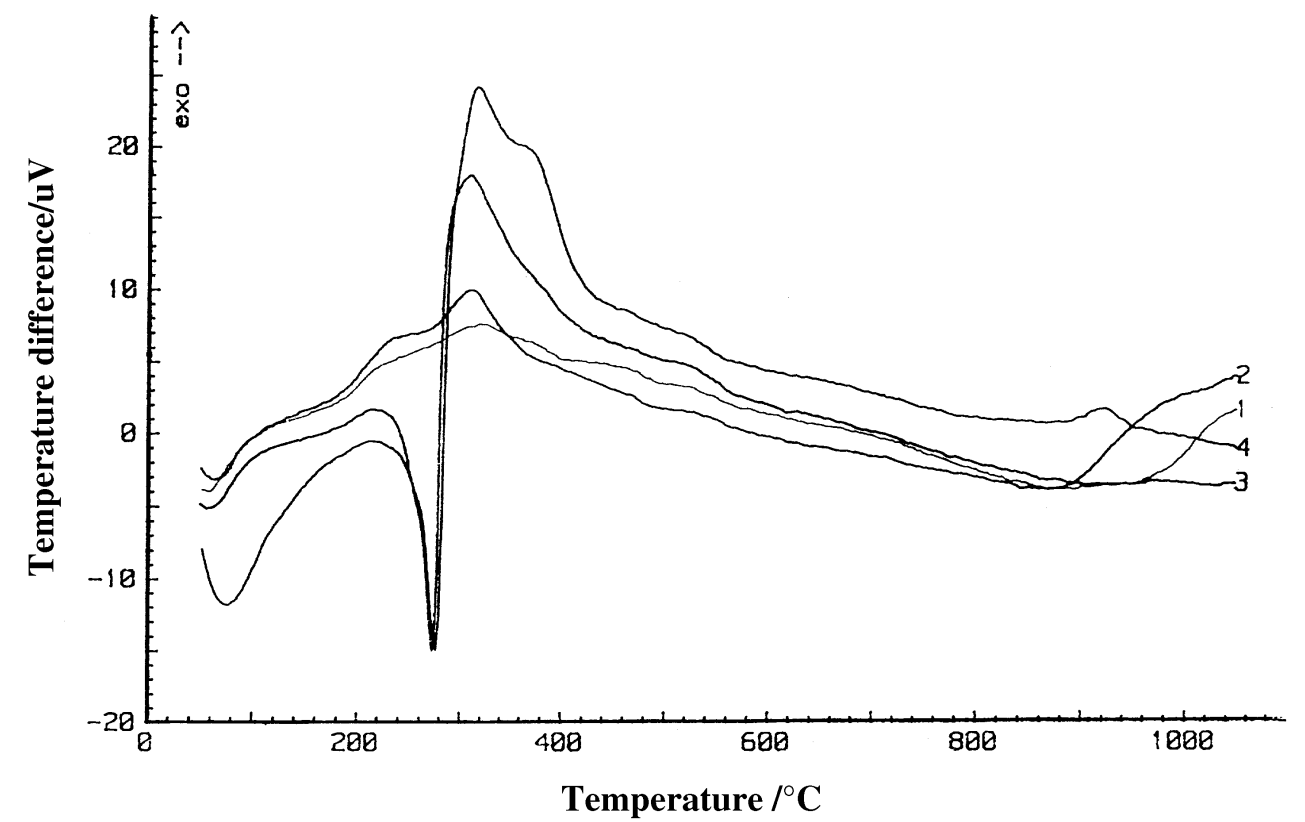

FIg. 9. DTA curves, $1=\# 1 \mathrm{C}$ horizon; $2=\# 2 \mathrm{Bw}$ horizon; $3=\# 3$ Bs horizon, $4=\# 4$ Bs horizon.

present only in the $\mathrm{B}$ horizons and the amount increases from $4.9 \mathrm{wt} \%$ in the $\mathrm{Bw}$ horizon of soil $\# 2$ to $32.7 \mathrm{wt} \%$ in the Bs horizon of soil \#4. As shown in Fig. 10, the increase in the amount of gibbsite is a non-linear function of time.

Total chemical analysis and accessible permanent charge. Total chemical analyses and accessible permanent charge for the fine clay samples from the $\mathrm{Bw}, \mathrm{Bs}, \mathrm{A}$ and $\mathrm{E}$ horizons are given in Table 3. For the $\mathrm{Bw}$ and $\mathrm{Bs}$ horizon samples the prominent feature is the decrease with time of the $\mathrm{MgO}, \mathrm{Fe}_{2} \mathrm{O}_{3}$ and $\mathrm{K}_{2} \mathrm{O}$ contents. Accessible permanent charge decreases in the $\mathrm{B}$ horizons from $24.70 \mathrm{cmol}_{+} \mathrm{kg}^{-1}$ (soil \#2 Bw horizon) to $9.50 \mathrm{cmol}_{+} \mathrm{kg}^{-1}$ (soil \#4 Bs horizon). This is in good agreement with the increasing weathering of phyllosilicate clays in $\mathrm{Bw}$ and Bs horizons as the time of soil development increases. For the $\mathrm{A}$ and $\mathrm{E}$ horizon samples, there is also a decrease in the $\mathrm{K}_{2} \mathrm{O}, \mathrm{MgO}$ and $\mathrm{Fe}_{2} \mathrm{O}_{3}$ contents, but the decrease in the $\mathrm{K}_{2} \mathrm{O}$ content with time is less pronounced than in the $\mathrm{Bw}$ and $\mathrm{Bs}$ horizons. The accessible permanent charge increases from $24.5 \mathrm{cmol}_{+} \mathrm{kg}^{-1}$ in soil \#2 (A horizon) to $30.5 \mathrm{cmol}_{+} \mathrm{kg}^{-1}$ in soil \#4 (E horizon). This is consistent with the XRD results indicating smectite and mica-smectite mixed-layers in these horizons.

\section{DISCUSSION}

Particle size distribution and chemical data from the $\mathrm{C}$ horizon samples show that all the soils have the same uniform parent material and so these soils can be considered to form a chronosequence, the main pedogenetic process being podzolization. The podzolization process is clearly demonstrated by the increasing amounts of amorphous forms of $\mathrm{Al}$ and $\mathrm{Fe}$ hydroxides $\left(\mathrm{NH}_{4}\right.$ oxalate extractable) which were translocated from the upper A and E horizons to the $\mathrm{Bw}$ and $\mathrm{Bs}$ horizons.

The rate of formation of pedogenic clays $(<2 \mu \mathrm{m})$ was greater during the early stages of soil

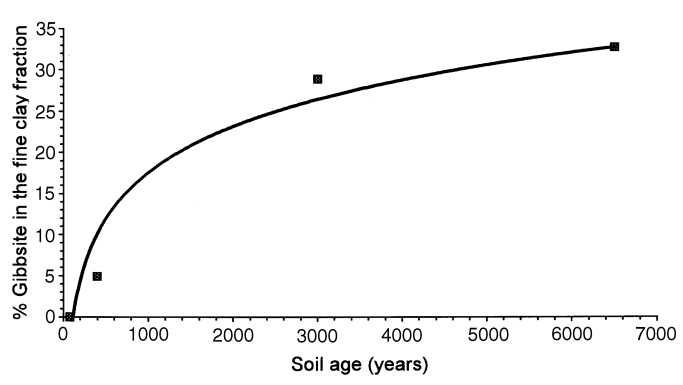

Fig. 10. Amount of gibbsite in the fine clay fractions from $\mathrm{Bw}$ and Bs horizons vs. time of soil development. 
TABLE 3. Chemical composition of fine clay fractions as percentage of $1000^{\circ} \mathrm{C}$ dry sample.

\begin{tabular}{|c|c|c|c|c|c|c|c|c|c|c|c|}
\hline Soil, horizon & $\mathrm{SiO}_{2}$ & $\mathrm{Al}_{2} \mathrm{O}_{3}$ & $\mathrm{Fe}_{2} \mathrm{O}_{3}$ & $\mathrm{MnO}$ & $\mathrm{MgO}$ & $\mathrm{CaO}$ & $\mathrm{Na}_{2} \mathrm{O}$ & $\mathrm{K}_{2} \mathrm{O}$ & $\mathrm{TiO}_{2}$ & LOI & $\begin{array}{c}\mathrm{APC} \\
\mathrm{cmol}_{\mathrm{c}} \mathrm{kg}^{-1}\end{array}$ \\
\hline$\# 1 \mathrm{C}$ & 50.83 & 20.73 & 14.82 & 0.26 & 5.51 & 0.51 & 1.80 & 5.44 & 1.02 & 5.60 & 13.10 \\
\hline \#2 A & 53.88 & 23.74 & 11.42 & 0.12 & 3.56 & 0.39 & 1.12 & 3.86 & 1.82 & 20.90 & 24.50 \\
\hline$\# 2 \mathrm{Bw}$ & 47.23 & 21.22 & 14.64 & 0.24 & 5.06 & 2.71 & 2.20 & 5.27 & 1.40 & 14.20 & 24.70 \\
\hline \#3 A & 53.54 & 23.68 & 10.56 & 0.12 & 3.66 & 0.73 & 1.17 & 4.10 & 1.79 & 18.00 & 25.00 \\
\hline$\# 3 \mathrm{Bs}$ & 34.82 & 48.97 & 8.70 & 0.12 & 2.78 & 0.40 & 0.72 & 3.31 & 1.75 & 22.30 & 11.70 \\
\hline$\# 4 \mathrm{E}$ & 54.16 & 30.46 & 5.32 & 0.03 & 2.04 & 0.74 & 0.80 & 3.35 & 2.99 & 13.50 & 30.50 \\
\hline \#4 Bs & 26.75 & 61.14 & 6.70 & 0.05 & 1.16 & 0.62 & 0.45 & 1.70 & 1.70 & 32.60 & 9.50 \\
\hline
\end{tabular}

ACP: accessible permanent charge

LOI: loss on ignition at $1000^{\circ} \mathrm{C}$

development as shown in Fig. 2, this could be attributed to the fast weathering of the $\mathrm{Fe}-\mathrm{Mg}$ trioctahedral minerals during the early stages of soil development. Instability of biotite and chlorite in soil environments is well documented (Fanning et al., 1989; Barnhisel \& Bertsch, 1989).

As shown by XRD and the analyses of the silt particles, the parent material contains chlorite, phengitic and biotitic micas as primary phyllosilicates.

Mineralogical evolution of silt-sized phyllosilicates follows different pathways according to their composition and the horizon in which they are located. In the $\mathrm{Bw}$ and $\mathrm{Bs}$ horizons, dioctahedral phengitic micas are preserved from intense weathering while $\mathrm{Fe}$-, Mg-rich biotitic micas were transformed into mica-vermiculite mixed-layers and vermiculite. In the $\mathrm{A}$ and $\mathrm{E}$ horizons, $\mathrm{Fe}-\mathrm{Mg}$ minerals have been, with time, completely weathered, and the dioctahedral phengite micas were partially transformed to an ordered mica-smectite mixed-layered mineral. The A and E horizons are where complexing organic acids are produced or translocated during podzolization. Removal of elements like $\mathrm{Fe}, \mathrm{Al}$ and $\mathrm{Mg}$ from the soil solution through complexation by complexing organic acids could be the reason for an enhanced weathering in these horizons. Because $\mathrm{Fe}$ complexes are more stable than other metal complexes, Fe-bearing phyllosilicates are expected to be less resistant to weathering when this complexation-removal mechanism is effective (Fanning et al., 1989).

The same contrasted mineralogical evolution is observed for the fine clay fractions. $\mathrm{Di}$ - and trioctahedral phyllosilicates are present in the fine clays from the parent material (C horizon soil $\# 1)$. Both were strongly weathered in the $\mathrm{Bw}$ and $\mathrm{Bs}$ horizons, but the trioctahedral fraction faster than the dioctahedral one, as indicated by the evolution of the relative intensities of the 060 XRD bands at $d=1.54$ and $1.51 \mathrm{~nm}$. The weathering intermediate phases are mica-vermiculite mixed-layers and vermiculite, and the end-products are gibbsite and $\mathrm{Fe}$ oxy-hydroxides. Formation of gibbsite in the $\mathrm{Bh}$ horizon of podzols was previously observed by Righi \& De Coninck (1977). Weathering of the trioctahedral fraction was faster in the A and E horizons than in the $\mathrm{B}$ horizons, being almost complete in soil \#3, 3000 years old. The weathering products did not accumulate in place but were translocated to the $\mathrm{Bw}$ and $\mathrm{Bs}$ horizons. They contribute to the accumulation of amorphous $\mathrm{Al}$ and $\mathrm{Fe}$ compounds and the formation of gibbsite in these horizons. As for the silt fractions, the transformation of the dioctahedral micas is observed in the fine clay fractions from the $\mathrm{A}$ and $\mathrm{E}$ horizons, giving ordered mica-smectite mixedlayers and smectite.

Smectite layers are also present in the fine clay from the $\mathrm{Bw}$ horizon of soil \#2, but their characters are different from those of the smectite from the A and $\mathrm{E}$ horizons. The smectite in the $\mathrm{Bw}$ horizon was less affected by acid treatment than the smectite in the $\mathrm{E}$ horizon, indicating a more aluminous chemical composition. This suggests that the smectite in the $\mathrm{Bw}$ and $\mathrm{A}$ or $\mathrm{E}$ horizons may not have the same origin, although it was not possible to elucidate the origin of the smectite in 
the Bw horizon. Formation by feldspar weathering, as demonstrated by Aoudjit et al. (1995), is one possibility.

The contrasted mineralogical evolution observed in eluvial ( $\mathrm{A}$ and $\mathrm{E}$ horizons) and illuvial (Bw and Bs horizons) is in good agreement with the concept of two geochemical compartments in podzolized soils (Ugolini et al., 1991). According to this concept, an upper compartment, that includes the A and $\mathrm{E}$ horizons, is dominated by organic acids as major proton donors. The low $\mathrm{pH}(\sim 4)$ and the metal complexing properties of the organic acids favour a weathering regime that leads to congruent dissolution of minerals. Aluminium and $\mathrm{Fe}$, released by weathering, are complexed by organic acids and translocated deeper in the profile. In the lower compartment, that includes the $\mathrm{Bs}$ and $\mathrm{C}$ horizons, carbonic acid is the major proton donor. Carbonic acid induces weathering characterized by incongruent mineral dissolution. Base cations and $\mathrm{Si}$ are leached leaving an $\mathrm{Al}$ and $\mathrm{Fe}$ residue. This was observed in the present study but essentially for the more weatherable $\mathrm{Fe}-\mathrm{Mg}$ phyllosilicates. Dioctahedral micas are more resistant and only slightly weathered, especially in the $\mathrm{Bw}$ and $\mathrm{Bs}$ horizons. However, the stronger weathering system in the upper compartment (A and $\mathrm{E}$ horizons) induces a transformation of dioctahedral mica, that does not occur in the lower compartment characterized by a less aggressive weathering system. The presence of these two system helps to explain the formation of smectite in acid strongly leached $\mathrm{E}$ horizons of Podzols and the presence of other or transformed minerals in the Bs (Zabowski \& Ugolini, 1992).

\section{CONCLUSION}

A mineralogical evolution was observed along a selected soil sequence representing a chronosequence. The most important feature of this chronosequence is an increase in the amount of clays $(<2 \mu \mathrm{m})$ and the contrasted evolution of triand dioctahedral phyllosilicates in the eluvial and the illuvial horizons. In the strongly aggressive system prevailing in the $\mathrm{A}$ and $\mathrm{E}$ horizons, $\mathrm{Fe}-\mathrm{Mg}$ and/or trioctahedral phyllosilicates were rapidly altered, their destruction being almost complete after 3000 years of soil development. Weathering products were translocated in the $\mathrm{Bs}$ and $\mathrm{Bh}$ horizons and contributed to the accumulation of amorphous $\mathrm{Fe}$ and $\mathrm{Al}$ oxy-hydroxides and to the crystallization of gibbsite in these horizons. Dioctahedral phyllosilicates were also weathered in this system, leading to the formation of smectites through ordered mica-smectite mixed-layers; these minerals are present after 400 years of soil development. Weathering appears to be less aggressive in the $\mathrm{Bw}$ and Bs horizons, only the $\mathrm{Fe}-\mathrm{Mg}$ and/or trioctahedral phyllosilicates were altered, giving vermiculite and finally $\mathrm{Fe}$ and $\mathrm{Al}$ oxy-hydroxides as residual products. The complete weathering of trioctahedral phyllosilicates in the fine clay fractions of these horizons require 6500 years of soil development.

\section{REFERENCES}

Anderson S.J. \& Sposito G. (1991) Cesium-adsorption method for measuring accessible structural surface charge. Soil Sci. Soc. Amer. J. 55, 1569-1576.

Aoudjit H., Robert M., Elsass F. \& Curmi P. (1995) Detailed study of smectite genesis in granite saprolites by analytical electron microscopy. Clay Miner. 30, 135-148.

Barnhisel R.I. \& Bertsch P.M. (1989) Chlorites and hydroxy-interlayered vermiculite and smectite. Pp. 729-788 in: Minerals in Soil Environments, 2nd edition (J.B. Dixon \& S.B. Weed, editors). Soil Science Society of America, Madison, Wisconsin, USA.

Bless R. (1984) Beiträge zur spät- und postglazialen Geschichte der Getscher im nordöstlichen MontBlanc Gebiet. Thesis Physische Geographie 15.

Burri M. (1974) Histoire et préhistoire glaciaires des vallées des Drances (Valais). Eclogae Geol. Helv. 67/1, 135-154.

Douglas L.A. (1989) Vermiculites. Pp. 635-674 in: Minerals in Soil Environments, 2nd edition (J.B. Dixon \& S.B. Weed, editors). Soil Science Society of America, Madison, Wisconsin, USA..

Fanning D.S., Keramidas V.Z. \& El-Desoky M.A. (1989) Micas. Pp. 551-634 in: Minerals in Soil Environments, 2nd edition (J.B. Dixon \& S.B. Weed, editors). Soil Science Society of America, Madison, Wisconsin, USA.

Greene-Kelly R. (1953) The identification of montmorillonoids in clays. J. Soil Sci. 4, 233-237.

Holzhauser H. (1984) Zur Geschichte des Aletschgletscher und des Fieschergletschers. In: vol. 13 (G. Furrer, W.A. Keller, M. Gamper \& J. Suter, editors). Geographisches Institut des Universität Zurich.

INRA (1995) Référentiel Pédologique. INRA éditions, Paris.

Jeanroy E. (1972) Analyse totale des silicates naturels par spectrophotométrie d'absorption atomique. 
Application au sol et à ses constituants. Chim. Anal. 54, 159-166.

Jenny H. (1941) Factors of Soil Formation. McGrawHill, New York.

Jenny H. (1980) The Soil Resource. Springer-Verlag, New York.

Lanson B. (1993) Decompxr, X-ray diffraction pattern decomposition program. ERM Poitiers, France.

Lowe D.J. (1986) Controls on the rates of weathering and clay minerals genesis in airfall tephras: a review and New Zealand case study. Pp. 265-330 in: Rates of Chemical Weathering of Rocks and Minerals (S.M. Colman \& D.P. Dethier, editors). Academic Press, London.

MacEwan D.M.C. \& Wilson M.J. (1980) Interlayer and intercalation complexes of clay minerals Pp.197-248 in: Crystal Structures of Clay Minerals and their X-ray Identification (G.W. Brindley \& G. Brown, editors). Mineralogical Society, London.

Mehra O. \& Jackson M.L. (1960) Iron oxide removal from soils and clays by dithionite-citrate system buffered with sodium bicarbonate. Clays Clay Miner. 7, 317-327.

Protz R., Ross G.J., Martini I.P. \& Terasmae J. (1984) Rate of podzolic soil formation near Hudson Bay, Ontario. Can. J. Soil Sci. 64, 31-49.

Reynolds R.C. (1985) Description of program NEWMOD for the calculation of the one-dimensional X-ray diffraction patterns of mixed-layered
Clays. R.C. Reynolds, 8 Brook Road Hanover, New Hampshire.

Righi D. \& Meunier A. (1991) Characterization and genetic interpretation of clays in an acid brown soil (Dystrochrept) developed in a granitic saprolite. Clays Clay Miner. 39, 519-530.

Righi D. \& De Coninck F. (1977) Mineralogical evolution in hydromorphic sandy soils and podzols in 'Landes du Médoc', France. Geoderma, 19, $339-359$

Schwertmann U. (1964) Differenzierung der Eisenoxide des Bodens durch Extraktion mit saurer Ammoniumoxalat-Lösung. Z. Pflanzenernähr. Bodenkd. 105, 194-202.

Soil Survey Staff (1992) Keys to Soil Taxonomy, 5th ed. SMSS Technical Monograph 19. Pocahontas Press, Blacksburg, VA.

Ugolini F.C. (1986) Processes and rates of weathering in cold and polar desert environments. Pp. 193-235 in: Rates of Chemical Weathering of Rocks and Minerals (S.M. Colman \& D.P. Dethier, editors). Academic Press, London.

Ugolini F.C., Dahlgren R., La Manna J., Nuhn W. \& Zachara J. (1991) Mineralogy and weathering processes in recent and holocene tephra deposits in the Pacific Northwest, USA. Geoderma, 51, 277-299.

Zabowski D. \& Ugolini F.C. (1992) Seasonality in the mineral stability of a subalpine Spodosol. Soil Sci. 154, 497-507. 